\title{
Wpływ objawów choroby na jakość życia osób ze stwardnieniem rozsianym*
}

\section{The impact of disease symptoms on the quality of life of people with multiple sclerosis}

\author{
Alicja Jeżuchowska ${ }^{\bowtie}$ \\ Pomorski Uniwersytet Medyczny w Szczecinie, Zakład Pielęgniarstwa, ul. Żołnierska 48, 71-210 Szczecin \\ Pomeranian Medical University in Szczecin, Department of Nursing \\ $\triangle$ alicja935@onet.pl
}

\begin{abstract}
Introduction: Multiple sclerosis is a chronic autoimmune disease, usually occurring between 20 and 40 years of age, where central nervous system demyelination occurs.

Materials and methods: After establishing cooperation with 5 departments of the Polish Society of Multiple Sclerosis in Poland and the Rehabilitation Center in Krakow, 179 questionnaires were obtained from people with multiple sclerosis. The study used diagnostic survey methods and standardized Quality of Life Questionnaire Short Form 36.

Results: The largest group were women, $72.63 \%$, the average disease duration was 13.18 years, the lowest quality of life values were the domain of social functioning $3.23 \pm 2$.0 points, pain sensation $4.44 \pm 2.7$ points and limitations resulting from the emotional state $8.02 \pm 6.8$ points. A statistically significant correlation was found between age, sex, duration of the disease $(p<0.05)$ in selected domains and dimensions. The results of the
\end{abstract}

analysis showed statistically significant correlations between the symptoms of the disease and the quality of life assessment in individual categories and dimensions $(p<0.05)$.

Conclusions: 1 . Assessment of the quality of life by patients with multiple sclerosis in particular domains is very diverse, with the lowest ranked domain concerning social contacts, the highest domain physical functioning and physical dimension. 2. Elderly people and those who have been suffering from multiple sclerosis for longer have rated their quality of life worse than younger and shorter suffering people. This applies mainly to the domain of physical functioning and the physical dimension. This is probably due to the disease process and adaptation to the changing conditions dictated by the progressive disease. 3 . The severity of disease symptoms in people with multiple sclerosis is associated with a decrease in the quality of life of these people.

Keywords: multiple sclerosis; quality of life; quality of functioning; impact of disease.

\begin{abstract}
ABSTRAKT
Wstęp: Stwardnienie rozsiane jest przewlekłą chorobą autoimmunologiczną, zwykle pojawiającą się ok. 20.-40. r.ż., w której dochodzi do demielinizacji ośrodkowego układu nerwowego. Materiały i metody: Po nawiązaniu współpracy z 5 oddziałami Polskiego Towarzystwa Stwardnienia Rozsianego w Polsce oraz z Centrum Rehabilitacji w Krakowie uzyskano 179 kwestionariuszy od osób chorych na stwardnienie rozsiane. W badaniach zastosowano metodę sondażu diagnostycznego oraz standaryzowany kwestionariusz jakości życia Short form 36.

Wyniki: Najliczniejszą grupę $(72,63 \%)$ tworzyły osoby płci żeńskiej, średni czas trwania choroby wynosił 13,18 lat, najniżej została oceniona jakość życia w domenie funkcjonowania społecznego $(3,23 \pm 2,0 \mathrm{pkt})$, odczuwania bólu $(4,44 \pm 2,7 \mathrm{pkt})$ oraz ograniczenia wynikającego ze stanu emocjonalnego $(8,02 \pm 6,8$ pkt). Wykazano statystycznie istotną korelację między wiekiem, płcią a czasem trwania choroby $(p<0,05)$ w wybranych domenach i wymiarach. Wyniki analizy wykazały statystycznie
\end{abstract}

istotne korelacje między występującymi objawami choroby a oceną jakości życia w poszczególnych kategoriach i wymia$\operatorname{rach}(\mathrm{p}<0,05)$.

Wnioski: 1. Ocena jakości życia przez pacjentów ze stwardnieniem rozsianym w poszczególnych domenach jest bardzo zróżnicowana, najniżej oceniana domena dotyczy kontaktów społecznych, najwyżej - funkcjonowania fizycznego i wymiaru fizycznego. 2. Osoby starsze oraz dłużej chorujące na stwardnienie rozsiane oceniały gorzej swoją jakość życia od osób młodszych i krócej chorujących. Dotyczy to głównie domeny funkcjonowania fizycznego oraz wymiaru fizycznego. Prawdopodobnie wynika to z procesu choroby i dostosowania się do zmieniających się warunków dyktowanych przez postępujące schorzenie. 3. Nasilenie objawów chorobowych u osób ze stwardnieniem rozsianym wiąże się jednocześnie z obniżeniem jakości życia tych osób.

Słowa kluczowe: stwardnienie rozsiane; jakość życia; jakość funkcjonowania; oddziaływanie choroby. 


\section{WSTĘP}

Stwardnienie rozsiane (multiple sclerosis - SM) jest przewlekłą chorobą autoimmunologiczną, zwykle pojawiającą się ok. 20.-40. r.ż., w której dochodzi do demielinizacji ośrodkowego układu nerwowego [1]. Można wyróżnić 4 postacie choroby charakteryzujące się wystąpieniem typowych objawów, czasem trwania rzutu bądź okresem remisji [2].

W początkowych fazach SM można zaobserwować wystąpienie takich symptomów, jak: drętwienie, mrowienie, ból kończyn. Późniejszymi objawami są zaburzenia równowagi, spastyczność, zaburzenia wzroku, nerwoból nerwu trójdzielnego, zaburzenia funkcji pęcherza moczowego i jelit, problemy z wymową, a także zaburzenia w sferze seksualnej. Należy pamiętać, że wymienione przypadłości nie występują wyłącznie w SM, dlatego diagnoza musi opierać się na wykluczeniu potencjalnych innych chorób neurologicznych [3, 4]. Skutkiem występowania objawów prowadzących często do obniżenia aktywności oraz niepełnosprawności jest zmniejszenie przeżycia średnio o 6-7 lat [5].

Celem pracy była ocena jakości życia pacjentów z SM w zależności od zmiennych (wiek, płeć, czas trwania choroby) oraz od nasilenia występujących objawów chorobowych.

\section{MATERIAtY I METODY}

Podjęto współpracę ze wszystkimi oddziałami Polskiego Towarzystwa Stwardnienia Rozsianego w Polsce, rozsyłając po 30 zestawów kwestionariuszy do każdego oddziału. Zwrotnie uzyskano 26 ankiet z oddziału w Radomiu, 19 z Łodzi, 9 z Ziemi Cieszyńskiej, 8 z Sieradza i 8 z Zakopanego. Ponadto uzyskano 30 kwestionariuszy z Centrum Rehabilitacji w Krakowie oraz 79 formularzy internetowych. W końcowej fazie uzyskano kwestionariusze badawcze od 179 osób chorujących na stwardnienie rozsiane.

Do badań zastosowano metodę sondażu diagnostycznego, a w celu zebrania danych wykorzystano standaryzowany kwestionariusz oceniający jakość życia Short form 36. Kwestionariusz zawiera 11 pytań określających 8 kategorii (funkcjonowania fizycznego, ograniczenia roli w funkcjonowaniu fizycznym, odczuwania bólu, ogólnego stanu zdrowia, witalności, funkcjonowania społecznego, ograniczenia wynikającego ze stanu emocjonalnego, zdrowia psychicznego). Wskaźnik jakości życia ułatwia ukazanie subiektywnej oceny stanu zdrowia. Kategorie zgrupowane są w wymiar fizyczny oraz mentalny jakości życia. W skali SF-36 odpowiedzi na każde z pytań są odpowiednio punktowane. Możliwa liczba punktów do uzyskania wynosiła 0-171 [6]

Kolejnym narzędziem wykorzystanym do badań była ankieta własna, która zawierała pytania dotyczące danych socjodemograficznych (wiek, płeć, stan cywilny, wykształcenie) i klinicznych (czas zdiagnozowania choroby, ocena nasilenia objawów, intensywność objawów). Badanie te nie wymagały zgody Komisji Bioetycznej.

Analizę statystyczną przeprowadzono, stosując program IBM SPSS w wersji 22 oraz arkusz kalkulacyjny Microsoft
Office Excel w wersji 2012. Uzyskane dane liczone na skali ilościowej z rozkładem zmiennych zbliżonym do rozkładu normalnego poddano analizie ilościowej, statystycznej i procentowej, wykorzystując współczynnik korelacji r Pearsona. Za istotne statystycznie przyjęto $\mathrm{p}<0,05$.

\section{WYNIKI}

Grupę badaną tworzyło 179 osób. Wiek ankietowanych mieścił się w przedziale 18-76 (średnia 46,21 $\pm 14,0$ ) lat. Osoby poniżej 30. r.ż. stanowiły $12,85 \%$, osoby w wieku 30.-39. r.ż. $22,91 \%$. Najliczniejszą grupę tworzyły osoby płci żeńskiej (72,63\%), mężczyzn było 27,37\%. Jedynie 17,88\% ankietowanych to osoby samotne, natomiast $56,98 \%$ to osoby żyjące w związku małżeńskim. W badaniu najliczniejszą grupę stanowiły osoby z wykształcenie wyższym - 40,78\%, kolejną grupę pod względem liczebności tworzyły osoby z wykształceniem średnim - 39,66\%. Najliczniejszą grupą badanych były osoby zamieszkujące miasta powyżej 100 tys. mieszkańców 45,81\%. Aglomeracje, które liczą poniżej 100 tys. mieszkańców, zamieszkiwało 20,11\% badanych osób.

Czas choroby od momentu zdiagnozowania SM u ankietowych wahał się od 0,5 roku do 50 lat. Średni czas trwania choroby wynosił 13,18 \pm 10 , 9 lat. Spośród wszystkich uczestników badania 46,37\% chorowało na SM krócej niż 10 lat, natomiast wśród 26,82\% ankietowanych osób czas trwania choroby wynosił 10-19 lat (ryc. 1).

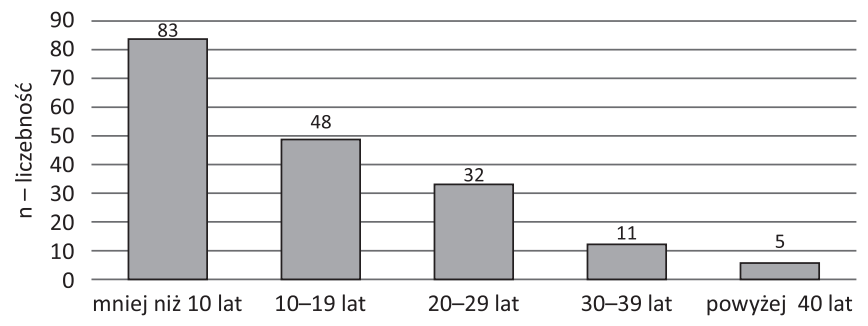

RYCINA 1. Charakterystyka grupy ze względu na czas choroby od momentu zdiagnozowania

Analiza poszczególnych objawów choroby wykazała, że najwięcej osób miało bardzo nasilone objawy męczliwości - 40,22\%, natomiast najmniej cierpiało z powodu zaburzeń mowy $-5,59 \%$.

Uczestnicy badania określali stopień swojej jakości życia w 8 domenach. Najniżej została oceniona jakość życia w domenie funkcjonowania społecznego - 3,23 $\pm 2,0$ pkt, odczuwania bólu $-4,44 \pm 2,7$ pkt oraz ograniczenia wynikającego ze stanu emocjonalnego - 8,02 $\pm 6,8$ pkt, natomiast najwyżej w funkcjonowaniu fizycznym - 28,06 $\pm 14,23$ pkt, wymiarze fizycznym $-59,52 \pm 23,1$ pkt oraz mentalnym - 31,99 \pm 13 pkt (tab. 1).

W wyniku analizy danych między wiekiem a oceną jakości życia wg skali SF-36 zauważono występowanie zależności w domenach funkcjonowania fizycznego $(p=0,000)$, odczuwania bólu $(p=0,012)$ oraz wymiaru fizycznego $(p=0,000)$. Średnia moc zależności występowała dla funkcjonowania 
TABELA 1. Charakterystyka grupy ze względu na ocenę jakości życia pacjentów

\begin{tabular}{|c|c|c|c|c|c|}
\hline SF-36 & $\mathbf{n}$ & Min. & Maks. & M & SD \\
\hline Funkcjonowanie fizyczne & 179 & 0 & 50 & 28,06 & 14,233 \\
\hline Ograniczenie roli w funkcjonowaniu fizycznym & 179 & 0 & 20 & 12,07 & 8,308 \\
\hline Odczuwanie bólu & 179 & 0 & 9 & 4,44 & 2,667 \\
\hline Ogólny stan zdrowia & 179 & 3 & 25 & 14,95 & 4,263 \\
\hline Witalność & 179 & 1 & 20 & 10,35 & 3,634 \\
\hline Funkcjonowanie społeczne & 179 & 0 & 8 & 3,23 & 2,006 \\
\hline Ograniczenia wynikające ze stanu emocjonalnego & 179 & 0 & 15 & 8,02 & 6,837 \\
\hline Zdrowie psychiczne & 179 & 0 & 25 & 10,39 & 4,865 \\
\hline Wymiar fizyczny jakości życia & 179 & 4 & 103 & 59,52 & 23,132 \\
\hline Wymiar mentalny jakości życia & 179 & 2 & 62 & 31,99 & 13,372 \\
\hline
\end{tabular}

n - liczebność; Min.-Maks. - minimum-maksimum; $\mathrm{M} \pm S D$ - średnia \pm odchylenie standardowe

fizycznego $(r=0,453)$ oraz wymiaru fizycznego jakości życia ( $p=0,338)$, co oznacza, że osoby młodsze lepiej oceniały jakość życia w tych wymiarach niż osoby w starszym wieku.

Występowała również zależność między czasem choroby a oceną jakości życia w aspekcie funkcjonowania fizycznego $(p=0,000)$ i wymiaru fizycznego jakości życia $(p=0,000)$. Zależność dodatnia oraz istotna statystycznie jej moc dla funkcjonowania fizycznego jest średnia $(r=0,333)$, a dla pozostałych wyników słaba $(r=0,261 ; r=0,198)$. Z analizy wynika, że osoby, które dłużej chorowały na SM, gorzej oceniały jakość życia w tych wymiarach od osób z krótszym czasem trwania choroby (tab. 2).

Wykazano także statystycznie istotną różnicę między średnią liczbą punktów dla oceny jakości życia w wymiarze funkcjonowania fizycznego wśród kobiet i mężczyzn. Chore na SM kobiety oceniały gorzej jakość życia w tej kategorii $(M \pm S D=26,51 \pm 13,4)$ niż mężczyźni $(M \pm S D=32,18 \pm 15,5$; $\mathrm{p}=0,017)$. Występowały także różnice między oceną odczuwania bólu i zdrowia psychicznego w zależności od płci $(\mathrm{p}=0,002)$. Mężczyźni lepiej oceniali jakość życia w aspekcie odczuwania bólu oraz jakości zdrowia psychicznego.

TABELA 2. Analiza zależności między wiekiem i czasem choroby a jakością życia

\begin{tabular}{lcccc} 
& \multicolumn{2}{c}{ Wiek } & \multicolumn{2}{c}{ Czas choroby } \\
\cline { 2 - 5 } & $\mathbf{r}$ & $\mathbf{p}$ & $\mathbf{r}$ & $\mathbf{p}$ \\
\hline Funkcjonowanie fizyczne & 0,453 & 0,000 & 0,333 & 0,000 \\
\hline $\begin{array}{l}\text { Ograniczenie roli } \\
\text { w funkcjonowaniu fizycznym }\end{array}$ & 0,126 & 0,093 & 0,13 & 0,084 \\
\hline Odczuwanie bólu & 0,187 & 0,012 & 0,098 & 0,191 \\
\hline Ogólny stan zdrowia & $-0,04$ & 0,591 & $-0,013$ & 0,862 \\
\hline Witalność & $-0,034$ & 0,65 & $-0,013$ & 0,868 \\
\hline Funkcjonowanie społeczne & 0,02 & 0,788 & $-0,007$ & 0,926 \\
\hline $\begin{array}{l}\text { Ograniczenia wynikające } \\
\text { ze stanu emocjonalnego }\end{array}$ & 0,113 & 0,13 & 0,068 & 0,368 \\
\hline Zdrowie psychiczne & 0,024 & 0,752 & 0,005 & 0,951 \\
\hline Wymiar fizyczny jakości życia & 0,338 & 0,000 & 0,261 & 0,000 \\
\hline Wymiar mentalny jakości życia & 0,06 & 0,422 & 0,032 & 0,672 \\
\hline
\end{tabular}

p - współczynnik istotności statystycznej; r - współczynnik korelacji Pearsona
Wyniki analizy wykazały statystycznie istotne korelacje $(\mathrm{p}<0,05)$ między zaburzeniami napięcia mięśniowego (spastyczność, problemy z utrzymaniem równowagi i koordynacją ruchów) oraz zaburzeniami mowy a pozostałymi domenami jakości życia, oprócz zdrowia psychicznego i witalności. Im chorzy na SM mieli bardziej nasilone zaburzenia napięcia mięśniowego i mowy, a także problemy z koordynacją i utrzymaniem równowagi, tym gorzej oceniali jakość życia w tych obszarach w porównaniu z osobami o mniej nasilonych objawach.

Zauważono także zależność ( $\mathrm{p}<0,05)$ między zaburzeniem wzroku a ograniczeniem roli w funkcjonowaniu fizycznym, odczuwaniem bólu, ograniczeniem wynikającym ze stanu emocjonalnego, a także wymiarem mentalnym jakości życia. Korelacja jest ujemna, a zależność o słabej mocy (tab. 3).

Wyniki analizy wykazały istotne statystycznie korelacje między męczliwością, zaburzeniami w sferze seksualnej oraz zaburzeniami emocjonalnymi a oceną jakości życia we wszystkich kategoriach i wymiarach $(\mathrm{p}<0,05)$. Oznacza to, że im osoba chora na SM miała bardziej nasiloną męczliwość, zaburzenia w sferze seksualnej i zaburzenia emocjonalne, tym gorzej oceniała jakość życia w tych aspektach.

Dla oceny funkcjonowania fizycznego ( $p=0,000)$, ogólnego stanu zdrowia $(\mathrm{p}=0,003)$ i wymiaru fizycznego jakości życia ( $p=0,000)$ występowała zależność istotna statystycznie między zaburzeniami funkcji pęcherza moczowego i jelit. Z analizy wynika, że im ankietowani mieli bardziej nasilone zaburzenia funkcji pęcherza moczowego i jelit, tym gorzej oceniali jakość życia dla tych aspektów niż osoby o mniej nasilonych objawach.

Występowała także statystycznie istotna korelacja $(\mathrm{p}<0,05)$ między nadwrażliwością na ciepło a pozostałymi domenami, oprócz odczuwania bólu. Z analizy wynika, że im osoba chora na SM miała bardziej nasiloną nadwrażliwość na ciepło, tym charakteryzowała się gorszą jakością życia w tych aspektach (tab. 4).

\section{DYSKUSJA}

W wynikach badań własnych zauważono niski poziom jakości życia osób dotkniętych SM. Zauważono zależność między wiekiem, czasem trwania choroby a jakością życia 
TABELA 3. Analiza zależności pomiędzy oceną jakości życia a objawami SM

\begin{tabular}{|c|c|c|c|c|c|c|c|c|}
\hline \multirow{3}{*}{ SF-36 } & \multicolumn{8}{|c|}{ Objawy stwardnienia rozsianego } \\
\hline & \multicolumn{2}{|c|}{$\begin{array}{c}\text { zaburzenia napięcia } \\
\text { mięśniowego - } \\
\text { spastyczność }\end{array}$} & \multicolumn{2}{|c|}{$\begin{array}{c}\text { zaburzenia } \\
\text { wzroku }\end{array}$} & \multicolumn{2}{|c|}{$\begin{array}{c}\text { problemy z utrzymaniem } \\
\text { równowagi i koordynacją } \\
\text { ruchów }\end{array}$} & \multicolumn{2}{|c|}{$\begin{array}{c}\text { zaburzenia } \\
\text { mowy }\end{array}$} \\
\hline & $r$ & p & $\mathbf{r}$ & p & $\mathbf{r}$ & p & $\mathbf{r}$ & $\mathrm{p}$ \\
\hline Funkcjonowanie fizyczne & $-0,547$ & 0,000 & $-0,097$ & 0,198 & $-0,526$ & 0,000 & $-0,219$ & 0,003 \\
\hline Odczuwanie bólu & $-0,265$ & 0,000 & $-0,15$ & 0,045 & $-0,246$ & 0,001 & $-0,18$ & 0,016 \\
\hline Ogólny stan zdrowia & $-0,288$ & 0,000 & $-0,041$ & 0,586 & $-0,333$ & 0,000 & $-0,152$ & 0,043 \\
\hline Witalność & $-0,086$ & 0,253 & $-0,109$ & 0,148 & $-0,13$ & 0,082 & $-0,096$ & 0,199 \\
\hline Funkcjonowanie społeczne & $-0,245$ & 0,001 & $-0,14$ & 0,062 & $-0,235$ & 0,002 & $-0,223$ & 0,003 \\
\hline Zdrowie psychiczne & $-0,102$ & 0,174 & $-0,146$ & 0,05 & $-0,067$ & 0,371 & $-0,061$ & 0,418 \\
\hline Wymiar fizyczny jakości życia & $-0,535$ & 0,000 & $-0,147$ & 0,05 & $-0,531$ & 0,000 & $-0,26$ & 0,000 \\
\hline Wymiar mentalny jakości życia & $-0,229$ & 0,002 & $-0,188$ & 0,012 & $-0,26$ & 0,000 & $-0,234$ & 0,002 \\
\hline Indeks jakości życia & $-0,473$ & 0,000 & $-0,181$ & 0,015 & $-0,483$ & 0,000 & $-0,28$ & 0,000 \\
\hline
\end{tabular}

p - współczynnik istotności statystycznej; r - współczynnik korelacji Pearsona

TABELA 4. Analiza zależności pomiędzy oceną jakości życia a pozostałymi objawami stwardnienia rozsianego

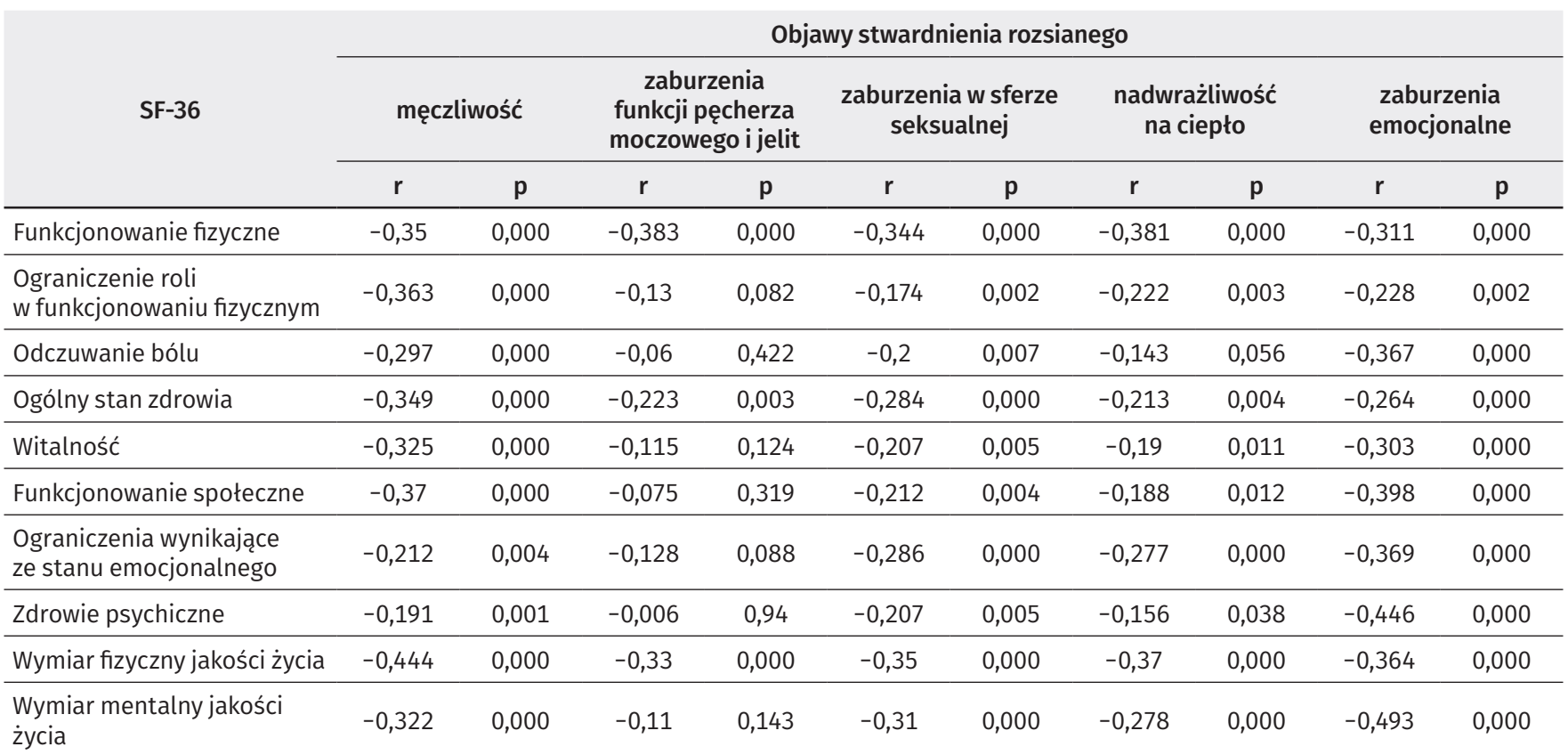

p - współczynnik istotności statystycznej; r - współczynnik korelacji Pearsona

w funkcjonowaniu fizycznym wskazującą, że osoby młodsze lepiej oceniały jakość życia od osób starszych. Wynikać to mogło zarówno z charakteru choroby, jak i jej nieznanego dalszego przebiegu.

Podobne wyniki uzyskały Drewniak i Śliwka [7], które podjęły się przeprowadzenia badania wśród 35 osób z SM za pomocą kwestionariusza oceny jakości życia SF-36 oraz skali MSIS-29, służącej do określenia wpływu SM na życie codzienne. Zbadały także sprawność funkcjonalną chorych testem Timed Up \& Go na skali DeSouza. Badania wykazały, że poziom jakości życia z uwagi na lata choroby, sprawność funkcjonalną oraz czas, jaki upłynął od momentu postawienia diagnozy, są niskie. Do podobnych wniosków doszły także Karakiewicz i wsp. [8], które przeprowadzając wśród 64 osób badanie oparte na kwestionariuszu SF-36, również zauważyły wpływ czasu choroby na jakość życia w domenie funkcjonowania fizycznego, emocjonalnego oraz ogólnego stanu zdrowia. Stwierdziły także brak zależności pomiędzy płcią 
a jakością życia pacjentów. W badaniach własnych wykazano natomiast, iż płeć ankietowanych ma wpływ na ocenę jakości życia. Chore na SM kobiety miały gorszą jakość życia w wymiarze funkcjonowania fizycznego, odczuwania bólu oraz zdrowia psychicznego. Miller i Dishon [9] sugerują, że kobiety chore na SM w porównaniu z mężczyznami mają większe trudności wynikające z występujących objawów, które mają duży wpływ na codzienne funkcjonowanie. Jednak nie zawsze musi występować jakikolwiek wpływ płci na ocenę jakości życia, czego dowiodła Kossakowska [10].

W 2016 r. Mickiewicz i Garczyński [11] opublikowali artykuł na temat możliwości funkcjonalnych chorych na SM w zależności od czasu trwania choroby. Badanie przeprowadzili wśród 25 kobiet i 15 mężczyzn chorych na SM uczestniczących w programie modulującym na Oddziale Neurologii SPWSZ w Szczecinie oraz należących do Polskiego Stowarzyszenia Stwardnienia Rozsianego w Szczecinie. Użyli niestandaryzowanego kwestionariusza własnego autorstwa. Chorzy zostali podzieleni na grupę A - osoby chore do 5 lat, B - 6-15 lat, C - powyżej 16 lat. Z uwagi na wczesne rozpoznanie choroby oraz wdrożenie odpowiedniego leczenia osoby z grupy A nie wykazywały problemów ze strony samodzielnego funkcjonowania, w przeciwieństwie do osób z grupy B i C. Wyniki autorów także potwierdziły występowanie zależności między czasem trwania choroby a oceną funkcjonowania osób z SM.

$\mathrm{Z}$ analizy badań własnych dotyczących zależności między zaburzeniami w sferze seksualnej a oceną jakości życia wg SF-36 zauważono statystycznie istotną zależność. Osoby, które skarżyły się na pogorszenie aktywności seksualnej od momentu zdiagnozowania SM, gorzej oceniały swoją ogólną jakość życia. Do podobnych wniosków doszli Lew-Starowicz i Rola [12], przeprowadzając badanie wśród 137 kobiet z SM. Wykazali zmniejszone zainteresowanie kontaktami płciowymi oraz spadek odczuwania przyjemności w trakcie zbliżenia. Przedstawili problem zaburzeń seksualnych jako jeden z najczęściej występujących objawów SM u kobiet, który znacznie wpływa na ocenę jakości życia.

Nagłe wystąpienie choroby wiąże się często z pojawieniem się stresu i koniecznością wypracowania sposobu radzenia sobie w trudnych sytuacjach. Z przeprowadzonych badań własnych wynika, że osoby z zaburzeniami emocjonalnymi gorzej oceniały jakość swojego życia w każdym aspekcie funkcjonowania. Rzeszutko i Rolińska [13] opisały możliwości wypracowania strategii do dalszego funkcjonowania w przypadku diagnozy SM. Zauważyły istotny wpływ wieku, płci, postaci klinicznej choroby, czasu jej trwania oraz ogólnej sprawności na sposób radzenia sobie. Kossakowska [14] przeprowadzając badanie na 60 osobach chorych i 60 zdrowych przy użyciu skali COPE, uzyskała odpowiedź na temat wykorzystywanych strategii chorych na SM. Dostrzegła częściej występujący u kobiet wybór religii jako dobrej strategii walki ze stresem. To właśnie kobiety częściej poszukują wsparcia emocjonalnego uzyskiwanego od rodziny i przyjaciół oraz szybciej akceptują swoją sytuację kliniczną w porównaniu z mężczyznami.

W badaniach prowadzonych wśród 93 pacjentów z SM oraz w grupie kontrolnej składającej się z 96 zdrowych osób
Klevan i wsp. [15] ukazali objawy oraz jakość życia osób z SM we wczesnej fazie choroby. Określili, że najczęstszym zgłaszanym objawem SM w pierwszych chwilach od momentu zdiagnozowania było zmęczenie, które dotyczyło aż 71\% chorych pacjentów. Kister i wsp. [3] wykorzystując rejestr Północnoamerykańskiego Komitetu Badawczego ds. Stwardnienia Rozsianego (NARCOMS), uzyskali dane od prawie 36000 pacjentów na temat nasilenia 11 najczęściej zgłaszanych objawów występujących w stwardnieniu rozsianym. O włączeniu do badania decydowało spełnienie następującego kryterium: czas trwania choroby 0-30 lat. Badanie wykazało pewien stopień nasilenia każdego symptomu choroby od momentu zdiagnozowania. Bardzo nasilone objawy choroby dotyczyły objawów sensorycznych (85\%), zmęczenia (81\%) i ruchliwości (50\%). $\mathrm{Z}$ upływem lat najszybciej postępującym objawem choroby ze stopnia umiarkowanego do ciężkiego była zdolność poruszania się, funkcja pęcherza moczowego i jelit oraz spastyczność. W wyniku analizy badań własnych także zauważono, iż z czasem trwania SM dochodziło do nasilenia objawów choroby. Występuje podobieństwo wyników własnych z wynikami Kister i wsp., głównie dotyczących nasilenia objawów ze strony zaburzeń napięcia mięśniowego (spastyczność), zaburzeń funkcji pęcherza moczowego i jelit oraz problemów z utrzymaniem równowagi i koordynacją ruchów [3].

\section{WNIOSKI}

1. Ocena jakości życia przez pacjentów z SM w poszczególnych domenach jest bardzo zróżnicowana, najniżej oceniana domena dotyczy kontaktów społecznych, najwyżej funkcjonowania fizycznego i wymiaru fizycznego.

2. Osoby starsze oraz dłużej chorujące na SM oceniały gorzej swoją jakość życia od osób młodszych i krócej chorujących. Dotyczy to głównie domeny funkcjonowania fizycznego oraz wymiaru fizycznego. Prawdopodobnie wynika to z procesu choroby i dostosowania się do zmieniających warunków dyktowanych przez postępujące schorzenie.

3. Nasilenie objawów chorobowych u osób z SM wiąże się jednocześnie z obniżeniem jakości życia tych osób.

\section{PIŚMIENNICTWO}

1. Solaro C, Trabucco E, Messmer Uccelli M. Pain and multiple sclerosis: pathophysiology and treatment. Curr Neurol Neurosci Rep 2013;13(1):320. doi: 10.1007/s11910-012-0320-5.

2. Khaled M, Koriem M. Multiple sclerosis: New insights and trends. Asian Pac J Trop Biomed 2016;6(5):429-44.

3. Kister I, Bacon TE, Chamot E, Salter AR, Cutter G, Kalina J, et al. Natural history of multiple sclerosis symptoms. Int J MS Care 2013;15(3):146-56. doi: 10.7224/1537-2073.2012-053.

4. Tullman M. Overview of the epidemiology, diagnosis, and disease progression associated with multiple sclerosis. Am J Manag Care 2013;19:15-20.

5. Guzik A, Kwolek A. Częstość występowania i rozmieszczenia stwardnienia rozsianego w Polsce i na świecie. Prz Med Uniw Rzesz Inst Leków 2015;1:55-62.

6. Tylka J, Piotrowicz R. Kwestionariusz oceny jakości życia SF-36 - wersja polska. Kardiol Pol 2009;67(10):1166-9. 
7. Drewniak A, Śliwka A. Ocena jakości życia oraz stanu funkcjonalnego chorych na stwardnienie rozsiane. Rehabil Med 2013;17(2):11-7.

8. Karakiewicz B, Stala C, Grochans E, Rotter I, Mroczek B, Zaremba-Pechmann L, et al. Ocena wpływu wybranych czynników socjodemograficznych na jakość życia osób chorujących na stwardnienie rozsiane. Ann Acad Med Stetin 2010;56(3):107-12.

9. Miller A, Dishon S. Health-related quality of life in multiple sclerosis: the impact of disability, gender and employment status. Qual Life 2006;15(2):259-71. doi: 10.1007/s11136-005-0891-6.

10. Kossakowska M. Standaryzacja polskiej wersji Kwestionariusza do Oceny Jakości Życia w Stwardnieniu Rozsianym (FAMS). Psychologia Jakości Życia 2004;3(1):61-80.
11. Mickiewicz P, Garczyński W. Możliwości funkcjonalne chorych na stwardnienie rozsiane w zależności od czasu trwania choroby. J Education Health Sport 2016;6(9):757-71.

12. Lew-Starowicz M, Rola R. Jakość życia seksualnego u kobiet chorujących na stwardnienie rozsiane. Prz Menopauz 2012;5:381-7.

13. Rzeszutko E, Rolińska A. Radzenie sobie ze stresem u chorych na stwardnienie rozsiane. Curr Probl Psychiatry 2011;12(3):293-300.

14. Kossakowska M. Strategie radzenia sobie z chorobą przewlekłą w stwardnieniu rozsianym. Post Psychiatr Neurol 2008;17(1):15-21.

15. Klevan G, Jacobsen C, Aarseth J, Myhr K, Nyland H, Glad S, et al. Health related quality of life in patients recently diagnosed with multiple sclerosis. Acta Neurol Scand 2013;129(1):21-6. doi: 10.1111/ane.12142. 